\title{
Endogenous Imbalances in a Single Currency Area*
}

\author{
Eszter Boros
}

This paper aims to identify the risks and real economic drivers of crises inherent in the monetary union over and above the current institutional challenges, seeking an answer to what fundamentally drives possible economic disturbances and what may impede the self-correction of markets. After analysing the available data, the author concludes that the euro area's real economic homogeneity and market adjustment performance exhibit a mixed picture. The centre-periphery fault line may both give rise to and preserve imbalances. The author concludes that to prevent this and to reap the expected benefits of the euro, a comprehensive and targeted competitiveness, structural and regional policy framework is called for.

Journal of Economic Literature (JEL) codes: E42, E52, F33, F36, F45

Keywords: single currency area, optimum currency areas, imbalances, euro area adjustment

\section{Single currency areas: the risk of an imbalance spiral}

The protracted crisis of the European Economic and Monetary Union (EMU) since 2010 and its slow recovery lend special relevance to the study of single currency areas. When seeking explanations and analysing the long-term viability of the area, identifying possible systemic issues, in addition to assessing individual member state responsibility and current crisis management, seems inevitable. If such issues are not addressed, they may pose recurring challenges to even adequately specified crisis management mechanisms.

The euro area crisis is a very complex set of issues stemming from global economic and financial developments, economic thinking that defines the adoption of the euro, a lack of adequate preliminary development of institutional frameworks and their loose application. The time that has elapsed since the onset of the crisis is apparently insufficient to clearly outline the emerging direction. At the same time, however, the entire period of the use of the euro is too brief and noisy to firmly

* The views expressed in this paper are those of the author(s) and do not necessarily reflect the offical view of the Magyar Nemzeti Bank.

Eszter Boros is a PhD candidate at the Department of Finance of Corvinus University of Budapest and a methodological specialist at the Magyar Nemzeti Bank.E-mail: borosesz@mnb.hu.

The manuscript was received on 19 November 2016.

DOI: http://doi.org/10.25201/FER.16.2.86118 
identify or rule out the significance of specific factors. It is underpinned by the fact that the introduction of a single currency is in and of itself a diverse (one-off) event, so the background and degree of the indirectly triggered processes may at least partially diverge from the impacts that prevail during long-term functioning. This paper therefore aims to identify the risks and real economic drivers of crises inherent in the monetary union, over and above the current institutional challenges. Although the elements of the special set of criteria described below and used with respect to the EMU in Part 3 may be linked to various degrees to the specific characteristics of the 2010 euro crisis, over the longer term, they may even play a pivotal role in the degree to which the monetary block must "permanently adopt crisis management".

As we know, the economies that make up the single currency area use a single currency in lieu of their own currency, which presumes uniform monetary policy. The key issue of this scheme is the constraint of zone-level assessment which creates an unsurmountable problem for the euro area's central bank. As long as an economy has its own currency and monetary policy, it can use the currency exchange rate as a channel for (at least) short-term adjustment, while markets have less power to push the entity into a liquidity crisis and ultimately, insolvency (Csajbók - Csermely 2002; Krugman - Obstfeld 2003; De Grauwe 2012a; De Grauwe 2013). ${ }^{1}$ By contrast, joining the monetary union means giving up the exchange rate tool and adopting a monetary policy tailored to the entire zone, which may render the generated (public) debt similar to foreign currency debt.

It can of course be assumed that small, open economies already have limited ability to take advantage of exchange rate adjustments and therefore giving up their own currency is not such a great sacrifice (Palánkai 2012). However, the risk of endogenous imbalance nuances this finding. It is not always possible to set an interest rate that is suited to the entire zone. Asymmetrical developments in certain regions of the area create a dilemma for the central bank: it either hikes the interest rate which curbs inflation in the region exhibiting an upswing and simultaneously deepens the recession in the other region, or does the opposite by attempting to prevent the risk of deflation in the latter while simultaneously further spurring inflation in the other regions by cutting the interest rate (Mundell 1961; McKinnon 1963; Kenen 1969). Whichever path it chooses, a harmful feedback is created within the system, and members of the currency area are highly likely to become stuck in imbalance unless alternative adjustment mechanisms come into play.

Although the literature typically presents this monetary policy paradox through the example of exogenous changes such as asymmetrical external demand shocks, the issue may also arise as a result of endogenous processes. This case is first and

\footnotetext{
${ }^{1}$ Ultimately, we can always presume that the entity can assume liabilities by creating money through its central bank.
} 
foremost linked to the introduction of the single currency and is very similar to the findings made with regard to the euro crisis (Part 2). Hale - Obstfeld (2014) offer a model-like presentation of the fact that if the creation of a monetary block entails a decline in internal loan interest rates, it not only increases gross capital flows, but also increases the proportion of intra-area financing. According to the model, cheaper credit means that projects with lower potential for success are also launched. This in turn results in the concentration of credit risk within the currency area. This also creates contradictory requirements for the zone's central bank (which also takes into account financial stability) if lending is markedly unidirectional. An initial interest rate decrease can be presumed in part due to transaction costs and in part due to the reduction of certain risks, but may obviously also stem from flawed risk perception and excessive market optimism. Due to the single key policy rate and financial market integration, the level of interest rates in member states cannot diverge significantly over a longer term (De Grauwe 2012a), so the problems of imbalance stemming from this must be faced later down the line. The likelihood of unilateral lending patterns increases in line with the area's heterogeneity. ${ }^{2}$ In such a scenario, addressing asymmetries is more difficult not only from a monetary, but also from a political perspective, as due to the internal inter-linkages, part of the zone's debt problems can only be resolved to the detriment and at the expense of the lending members (Baldwin et al. 2015).

The above facts confirm that, first and foremost, imbalances should be approached from a gross perspective. This is a novel stance insofar as - prior to the onset of the global financial crisis, during the period referred to as the "great moderation" - the severity of the financial stability consequences stemming from gross capital flows was not recognised (Bracke et al. 2010; Borio - Disyatat 2011; MNB 2011; MNB 2014). Gross flows and stocks deserve special attention because the assets of others are not available for the repayment of the debt of certain economic agents and sectors, even if the whole economy otherwise has extensive net external claims. The net external position, with the exception of valuation changes, varies in function of the joint balance of the current account and the capital account. The net financing deficit/surplus for the period is equal to the financial account of the balance of payments, which is, however, derived from financial transactions, the gross value of which is greater than their net balance. In the era of global financial markets, the difference between gross and net numbers takes on several orders of magnitude, and financing patterns are typically complex and feature variable risk profiles. At the same time, some arguments support the fact that the current account balance remains a relevant economic policy variable (Obstfeld 2012a). Financing positions that remain unidirectional for sustained periods are often symptoms of tensions accumulating within the economy. In the longer term, the economy's role as

\footnotetext{
${ }^{2}$ The Hale-Obstfeld model already pertains to the centre-periphery relationship within the area.
} 
borrower or lender determines the primary pressure on economic agents and the banking system. Unidirectional net patterns may signal unsustainable processes for the market, which is linked to the sudden stop of liquidity. (In a basic scenario, the [sovereign] members of currency areas are particularly sensitive to such situations. ${ }^{3}$ ) Thus, even if the great crisis of the past period and its ramifications did not present as a traditional current account crisis (MNB 2014), the growing unilateral swings of current accounts were indicative of the underlying imbalances.

These swings can be linked to the endogenous disturbances of currency areas in the following manner: In the case of asymmetrical developments, the entity in the positive branch will acquire a current account surplus in the wake of growing demand for its exports. It will also have the opportunity to lend to the economies buying its products (see De Grauwe - Ji 2012; De Grauwe 2013). Growing imports and decreasing exports give rise to the need for external borrowing (current account deficit) in the latter economies. Meanwhile, we arrive at the dilemma of a single monetary policy: inflation must be curbed in the first type of entity while deflation must be curbed in the second type, sooner or later. ${ }^{4}$ Let's assume that the central bank, focusing on the latter, cuts the interest rate. It is clear that in such a scenario, it is worthwhile for the second entity to borrow even more and to purchase even more from the former entity. Even if the local downturn/slump resolves, the current account deficit continues to swell simultaneously with the other entity's current account surplus. Here too, the accumulating debt is greater in gross terms and exhibits a more complex pattern, but the dynamics of the current account balance shed light on the imbalance disturbance in the case of this specific endogenous problem. A similar process can be described if the root of the asymmetry is a sudden decline in the price of financing, which means lower interest rates than before for a part of this area (see Hale-Obstfeld 2014).

The primary channels for preventing the endogenous spiral could be labour mobility and/or flexible price and wage adjustment. Labour mobility enables the area in the positive branch to absorb the labour of economies experiencing a downturn in the event of an asymmetric development. This decreases unemployment in the latter entity while mitigating (wage) inflationary pressure in the former entity. Price and wage adjustment theoretically impacts competitiveness according to a logic similar to the devaluation and appreciation of the exchange rate. If prices and wages fall in a currency area member in recession, exports and capital flows may increase and the economic downturn may resolve. In parallel, in the entities experiencing an upswing, rising prices and wages hurt competitiveness while rising import demand fosters successful internal devaluation (price and wage cuts) in

\footnotetext{
${ }^{3}$ Later in this paper, we address the practical differences that stem from currency area "simply" encompassing regions or sovereign states.

${ }^{4}$ The price level of domestic products decreases due to the slump in demand.
} 
the former economies. Unilateral current account dynamics are adjusted. An important observation is that competitiveness is not only made up of price-type factors. Whatever the case may be, the described mechanism certainly points to the necessity for one element, namely the importance of increasing the consumption (expenditure) of the economy experiencing an upswing during times of adjustment.

The brief presentation of alternative mechanisms also shows that this is a slower process that faces more obstacles compared to bespoke monetary policy and exchange rate-led adjustment. As a result, the sacrifices of joining the currency area cannot be ruled out. In other words: it is not a given that any economic grouping can operate a currency union. Although we have not stated it explicitly so far, it is apparent that certain benefits hoped for may create significant leeway for monetary unification efforts. For entities closely linked by trade and other areas, lower transaction costs, the avoidance or mitigation of exchange rate and other risks, improved price comparability and the resulting pick-up in trade and potentially even greater economic significance for the currency promise huge benefits.

Taken together, the substantial benefits and risks warrant the existence of guidance for investigating the viability of currency areas of differing composition.

The literature known as the theory of optimum currency areas (OCA) attempts to provide such points of reference. A currency area is optimal if it enables the dilemma of monetary policy to be averted. The conditions for an optimum currency area can be summed up as follows (Table $1^{5}$ ).

The most perfect functioning of the above alternative adjustment mechanisms is necessary: labour and capital mobility (1-2) and price and wage flexibility (3). With regard to the latter, it should be added that cutting prices and wages may encounter resistance and secondly, its impact is not always clear as it may exacerbate the burdens of deleveraging in the presence of indebtedness. Otherwise, it is characteristically slow, in which a coordination issue also plays a role (Krugman 2011).

\footnotetext{
${ }^{5}$ See also Benczes 2014; Szijártó 2014.
} 


\begin{tabular}{|c|c|c|}
\hline \multicolumn{3}{|c|}{$\begin{array}{l}\text { Table } 1 \\
\text { Optimality criteria and their economic reasons according to the OCA theory }\end{array}$} \\
\hline & Criterion & Link to optimality \\
\hline 1. & Labour mobility & $\begin{array}{l}\text { Supports the correction of imbalances } \\
\text { Obstacles: labour force heterogeneity, language and cultural } \\
\text { background }\end{array}$ \\
\hline 2. & $\begin{array}{l}\text { Capital mobility, integrated } \\
\text { financial markets }\end{array}$ & $\begin{array}{l}\text { Supports the correction of imbalances and risk-sharing and } \\
\text { synchronicity within the zone }\end{array}$ \\
\hline 3. & Price and wage flexibility & $\begin{array}{l}\text { Supports the correction of imbalances; Adjustment via internal } \\
\text { devaluation is not without its own issues even if there is sufficient } \\
\text { flexibility }\end{array}$ \\
\hline 4. & $\begin{array}{l}\text { Product market openness, } \\
\text { level of integration }\end{array}$ & $\begin{array}{l}\text { Multiplying benefits from using a single currency and (where } \\
\text { applicable) more limited sacrifices from losing the country's own } \\
\text { currency exchange rate }\end{array}$ \\
\hline 5. & Diversified economies & $\begin{array}{l}\text { No member should be substantially exposed to large-scale unilateral } \\
\text { (partial) economic shocks }\end{array}$ \\
\hline 6. & $\begin{array}{l}\text { Similarity of economic } \\
\text { structures }\end{array}$ & $\begin{array}{l}\text { Similar industrial structure, sectoral proportions, similar technologies } \\
\text { and work organisation within sectors, etc. creates greater symmetry }\end{array}$ \\
\hline 7. & $\begin{array}{l}\text { Synchronous business cycles, } \\
\text { similar inflationary } \\
\text { preferences and growth }\end{array}$ & Maintenance of symmetry \\
\hline 8. & $\begin{array}{l}\text { Similarity of institutional law, } \\
\text { culture and language }\end{array}$ & $\begin{array}{l}\text { Supports the maintenance of symmetrical situations and the } \\
\text { effectiveness of the necessary adjustments as a general framework }\end{array}$ \\
\hline
\end{tabular}

As discussed earlier, the sacrifice of losing the currency exchange rate is mitigated by the large degree of economic openness of members towards each other (4). This also multiplies the benefits stemming from the use of the single currency. With the requirement of diversified economies (5) the inclusion of excessively specialised members, who are thus unilaterally exposed to partial economic shocks, can be avoided. The similarity of economic structures (6) ensures that turbulences shift the economies in a similar direction. The synchronisation need also appears in the requirement pertaining to the matching of business cycles, the similarity of inflationary preferences and growth rates (7). The deviation of the latter factors results in certain entities being forced to accept outcomes other than their preferences for a sustained period. Finally, legal and institutional similarity, cultural and linguistic proximity (8) - as a supplement to the traditional OCA conditions - can be mentioned as a general framework condition of symmetry (8).

The theory of optimum currency areas fundamentally follows the cost-benefit principle when defining the composition of monetary blocks. Based on this feature, it can be linked to the metallist monetary theory which derives the value of money from the pursuit of efficiency by the private economy. In a broader sense, the OCA was created within the framework of the new classical economic mainstream, 
anchoring the primacy of market adjustment and monetary policy. Accordingly, it does not display the aspects that relate to the harmonisation of the scope of monetary and fiscal policies (Goodhart 1998; Barba - De Vivo 2013; Cesaratto 2015). Thus, it ignores the so-called cartelist approach (MNB 2011; Ábel et al. 2016), based on which a certain state involvement is necessary for the stability of money, or in a wording more tailored to our topic: some type of fiscal adjustment and coordination mechanism is needed. The existence or the lack of indications related to the uniform fiscal frameworks is relevant because it leads to differences in whether the members of the currency area can be regarded as "simple" regions or as countries. Markets perceive and treat the federal states of the USA differently than the member states of the euro area (Giavazzi - Spaventa 2010), which is attributable to a large extent to the degree of fiscal sovereignty of EU Member States. If we strictly follow the OCA criteria for defining the composition of a monetary block, we shall not incorporate fiscal coordination mechanisms or unify certain budgetary funds among the participants. ${ }^{6}$ In this sense, the framework can be considered deficient. But this deficiency does not make it unfit for the purposes of the study, that is, the analysis of the possibility of system-level tensions. Fiscal and other institutional mechanisms within the discourse related to currency areas primarily appear with a crisis management, crisis prevention and early warning function. Creating these functions may prove to be of fundamental importance (Part 2), but it fails to trace back all of the driving forces of imbalances and is unable to eliminate them.

In the following, this article reviews the background of the establishment of the EMU and the weaknesses revealed during the crisis (Part 2). Thereafter, it examines the performance in the euro area in terms of alternative adjustment mechanisms and the other homogeneity criteria of the OCA, with special regard to the period following 2010 (Part 3).

\section{The euro as a single currency}

Western European integration efforts had already yielded significant results by the 1960 s, such as total customs union, common agricultural policy, the uniformisation of product regulations and the free movement of persons. Members also cooperated in the coordination of monetary and exchange rate policies. Expanding relationships naturally presented the opportunity for the single currency, and in a timely manner, due to the demise of the Bretton Woods system and the increasing volatility of national currencies (Delors Report 1989; Ingram 1973; Krugman 2011). The attainable benefits seemed significant based on the estimates regarding the reduction of transactional costs, the elimination of exchange rate risk and the expansion of trade (Frankel - Rose 1998, 2002). Finally, the general introduction

\footnotetext{
${ }^{6}$ It is not certain that we shall not deal with fiscal issues at all, but these may primarily arise as the source of entity specific shocks (see Part 2).
} 
of the euro as a single currency took place in 2002. Today, the euro is the official means of payment of 19 EU Member States.

The crisis makes the evaluation of the euro's past fifteen years rather difficult if we accept the probable statement that the crisis is the result of systemic issues and harmful internal mechanisms. Some significant stability and macroeconomic risks associated with the currency union have materialised and represent substantial uncertainty for the future. Meanwhile, in terms of the attainable "traditional" benefits - reduction of transactional costs, etc. - the area may have obtained substantial profits, although the results and conclusions regarding the scale, the distribution and further prospects of such profits show great differences (Santos Silva - Tenreyro 2010; De Sousa 2011; Mongelli 2013; Petersen et al. 2013). As to how significant the convergence is among the economies and what direction it points to, the evidence is rather contradictory (see Neményi-Oblath 2012; Magas 2016). Part 3 addresses this issue.

When preparing for the single European currency, numerous authors used the OCA theory as an evaluation framework. Already during this period, results showed that the block of countries wanting to introduce the euro failed to meet the optimum currency area criteria in several respects. According to the summary of PisaniFerry (2012), asymmetries between member candidates, weak market adjustment mechanisms and the destabilisation risk of uniform monetary policy entailed by these factors appeared as an identified threat, which was difficult to estimate in advance. Although, as we know, it does not follow from the OCA theory, it is to be noted that already at the time of preparing for the currency union, there were some who drew attention to the significance of fiscal adjustment and coordination mechanisms (Godley 1992; Feldstein 1992).

At the same time, the edge of every identified problem was blunted by the frequent argumentation that the euro may endogenously transform the area into an OCA, because it accelerates economic integration, convergence and synchronization (OMOM Report 1990; Bayoumi - Eichengreen 1997; Frankel-Rose 1998; PisaniFerry 2012; Estrada et al. 2013). If a monetary union is an optimum currency area (OCA), in principle, it is able to avert endogenous disturbances. However, the 2010 crisis showed that "the process of perfection" of the expected speed certainly did not take place, and in a suboptimal scheme, broader economic policy coordination, a fiscal adjustment mechanism ensuring the stability of the single currency, and even coordinated macro-prudential policy are certainly needed. ${ }^{7}$ When the euro was

\footnotetext{
${ }^{7}$ It was only after the 2008 global crises that the relevance of this issue was more broadly recognised following the much higher capital flows, asset bubbles and financial imbalances (APFI). The need for macro-prudential policy is hence first warranted by general, global reasons rather than causes related to the currency area. It is another question that, as we have seen, in heterogeneous monetary blocks which are weak in alternative adjustment, the APFIs are given special endogenous incentives as well. Hence, all other things being equal, the higher the need for macro-prudential regulation, the less optimal the area.
} 
introduced, these aspects did not take hold, or they were applied with a different emphasis. Certain structural and regional funds were appropriated to mitigate economic differences between members (Delors Report 1989), but the magnitude of these funds was not substantial in the light of the wide-ranging fiscal powers and economic policy decision-making held by the Member States. The level of freedom of economic governance of the various Member States was accounted for as the source of entity-specific shocks. To handle the issue, fiscal sustainability rules were recommended first of all (Delors Report 1989; MNB 2011). The "no bail-out" declaration emphasised the rules, and at the same time, expressed the limitation of the risk community (Kiss J. 2011). While markets did not take this declaration seriously for a long time, when the crisis erupted, the uncertainty arising from it proved to be rather harmful. In a broader sense, this is related to the fact that when creating the EMU, neither crisis management procedures, nor any crisis management fund were institutionalised. The reason for this is that - in addition to the prospect of moral hazard - the great majority of systemic risks, and as such, the prospect for the private sector to become excessively indebted were not among the threats considered (Neményi - Oblath 2012; MNB 2011). The role of lender of last resort of the European Central Bank was also not clearly stipulated in the narrower monetary policy system (De Grauwe 2012b, 2013; Baldwin et al. 2015). ${ }^{8}$ Therefore, the EMU was created as an interim scheme in which members became regions from a monetary perspective, but otherwise remained sovereign states.

It follows from the foregoing that the common crisis explanations which associate the issues with the responsibility of the indebted economies are only partially valid. Non-compliance with the rules, overheated lending and protracted recovery as symptoms are the effects of the institutional background's weaknesses on the one hand and the endogenous disturbances presented in Part 1 on the other hand. Until 2010, economies on the periphery, i.e., Portugal, Spain, Greece, Italy and Ireland built up various forms of debt problems with practically the same background. In Greece and partially in Portugal, this was primarily manifested as government debt, but in Spain and Ireland, the indebtedness of the private sector (households, construction industry and banking sector) surged to an extremely high level, accompanied by asset price bubbles (as shown by Neményi - Oblath 2012). (These economies got into trouble despite the fact that their governments complied with the Maastricht criteria regarding public deficit and indebtedness for a long time.)

The lending boom after 2002 was made possible by the cheap loans flowing in from the centre of the zone, which were dominantly mediated by the banking sector by

\footnotetext{
${ }^{8}$ This can be clarified in that the central banks of the Member States still had certain leeway in defining and evaluating eligible collateral for central bank loans (Ruparel - Persson 2011). Thus, they can also classify among eligible collateral the government papers of the Member State. By doing so, commercial banks are incentivised to purchase these papers, which, in turn, may alleviate the Member State's financing difficulties. It is another question that all of this increases bank-state exposure, by increasing systemic risk.
} 
establishing complex bank-bank/bank-state interlacements. The single currency considerably deepened the integration of financial markets, both the magnitude and the ratio of gross capital flows among Member States surged, as the phenomenon of home bias decreased, and portfolio diversification in the euro area picked up momentum (De Grauwe 2012a; Pagano - von Tadden 2004). Money flows were driven by the level of interest rates fast becoming uniform, which meant low or even negative real interest rates for the countries in the periphery, which had previously only had access to more expensive financing. The reduction of transaction costs and the disappearance of exchange rate risks obviously played a role in that, but also some kind of erroneous risk perception which levelled the yield of periphery government bonds with that of German government securities. ${ }^{9}$ The debtor-creditor

\section{Figure 1}

Share of foreign banks within consolidated bank receivables from Greek residents

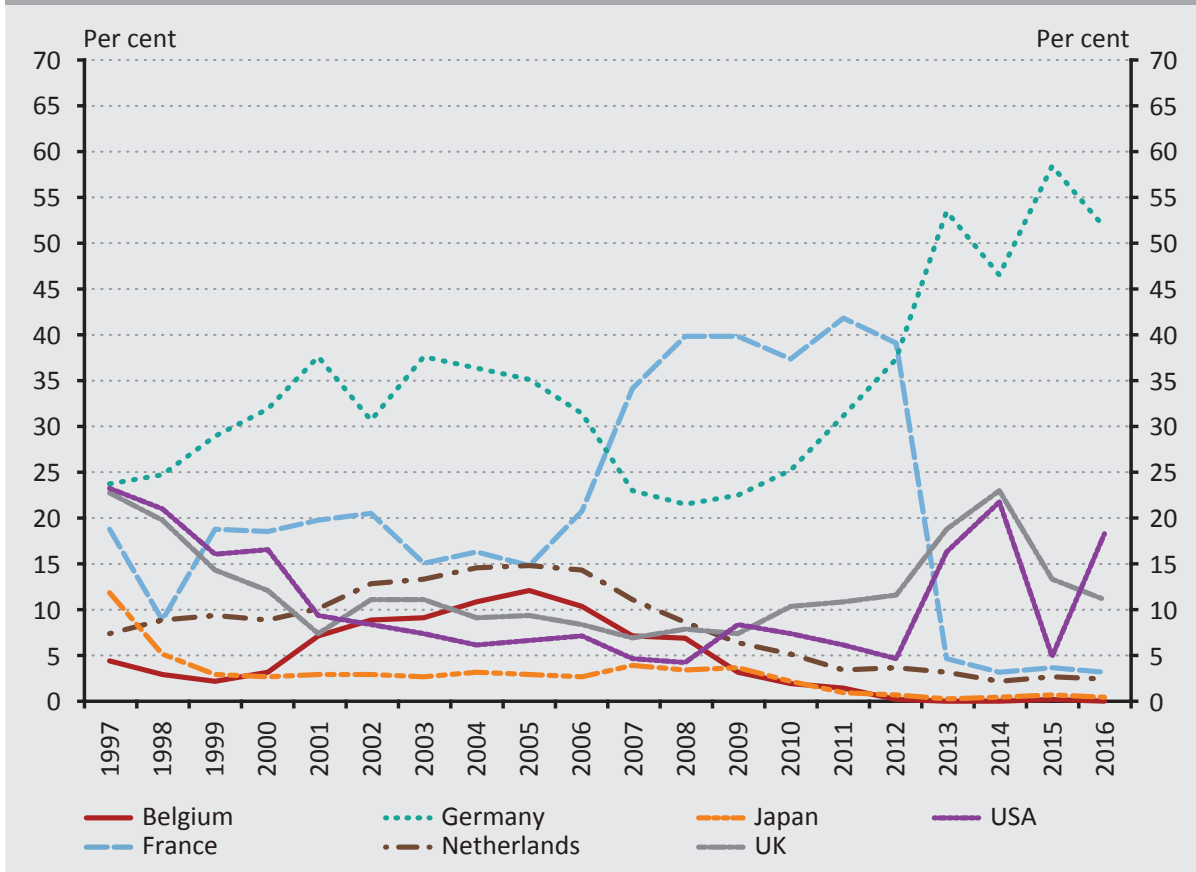

Note: The BIS data indicate the country of the bank depending on the head office of the ultimate shareholder. This way, the data contain the receivables of the Greek subsidiary banks from Greek residents (but not the receivables within the given bank group). The Figure only shows the foreign players with the largest receivables, therefore the sum of the shares does not add up to 100 per cent. The data for 2016 reflect the average of the first three quarters.

Source: Calculated based on the database of the Bank for International Settlements. "Consolidated positions on counterparties resident in Greece". http://stats.bis.org/statx/srs/table/b4?c=gr\&p=20153. Downloaded on 09 April 2016 and 15 March 2017.

\footnotetext{
${ }^{9}$ The time series of yields on 10-year government bonds of EU Member States can be found in: "Long-term Interest Rate Statistics for EU Member States", European Central Bank. https://www.ecb.europa.eu/stats/ money/long/html/index.en.html. Downloaded: 12 April 2016
} 
relationship illustrated in Figure 1 reflects the conclusions of Hale-Obstfeld (2014), according to which lending within the currency area shifts towards internal relations.

In Figure 1, we can clearly see the realignment of the structure of receivables of foreign banks from Greek residents: a decreasing share of creditors from outside the area between 1998 and 2008, and in parallel with this, an increased share of the volume of receivables of banks within the zone.

The mostly unilateral flow of credits primarily financed consumption and asset price bubbles on the periphery and not productivity and efficiency increasing investments. The boom in consumption primarily affected imported products and non-tradable goods (i.e. services). Thus, the utilisation of loans did not create the ability to repay external debt because it did not contribute to boosting future exports (Giavazzi - Spaventa 2010). During the initial years, it may have seemed that indebtedness is a natural consequence of economic convergence (Blanchard - Giavazzi 2002), but growth expectations proved to be exaggerated in view of the reasons mentioned in the foregoing.

In terms of the magnitude, the links among the players, the speculation related to the real estate bubbles and the not so prudent lending, capital flows can be approached from the perspective of the financial account, but the development of the crisis can also be clearly followed in the current account patterns. While the current accounts of the entire EMU remained in equilibrium vis-à-vis the global economy during the period under review, intra-euro area financing positions exhibited the proportions experienced between the USA and China (Schmitz - von Hagen 2011). Swings observable in Figure 2 represent the clearly unidirectional flows until 2008. ${ }^{10}$ The single monetary policy was unable to prevent imbalances, what is more, it further aggravated them because excessive lending on the periphery, and just as importantly, inflation exceeding the euro area average, would have required a higher interest rate, which did not seem justified for the other regions of the zone.

In 2010, the sudden outbreak of the crisis was essentially related to the fact that the market considered outstanding debt to be unsustainable. This cast a shadow on every economy of the euro area due to the interconnections among the banks and the states of the area, creating some kind of symmetrical situation for monetary policy (interest rate cut) during the next period. At the same time, the revelation of the risks entailed the widening of credit default swap premia. The direct stakeholders in this issue, i.e. the periphery states became isolated from

\footnotetext{
${ }^{10}$ Pasimeni (2016) also has an illustrative Figure which shows the developments in Germany's current-account balance vis-à-vis the euro area. It also shows similarly robust current account surpluses, explicitly indicating that the surpluses and shortages shown in Figure 2 "are matching".
} 


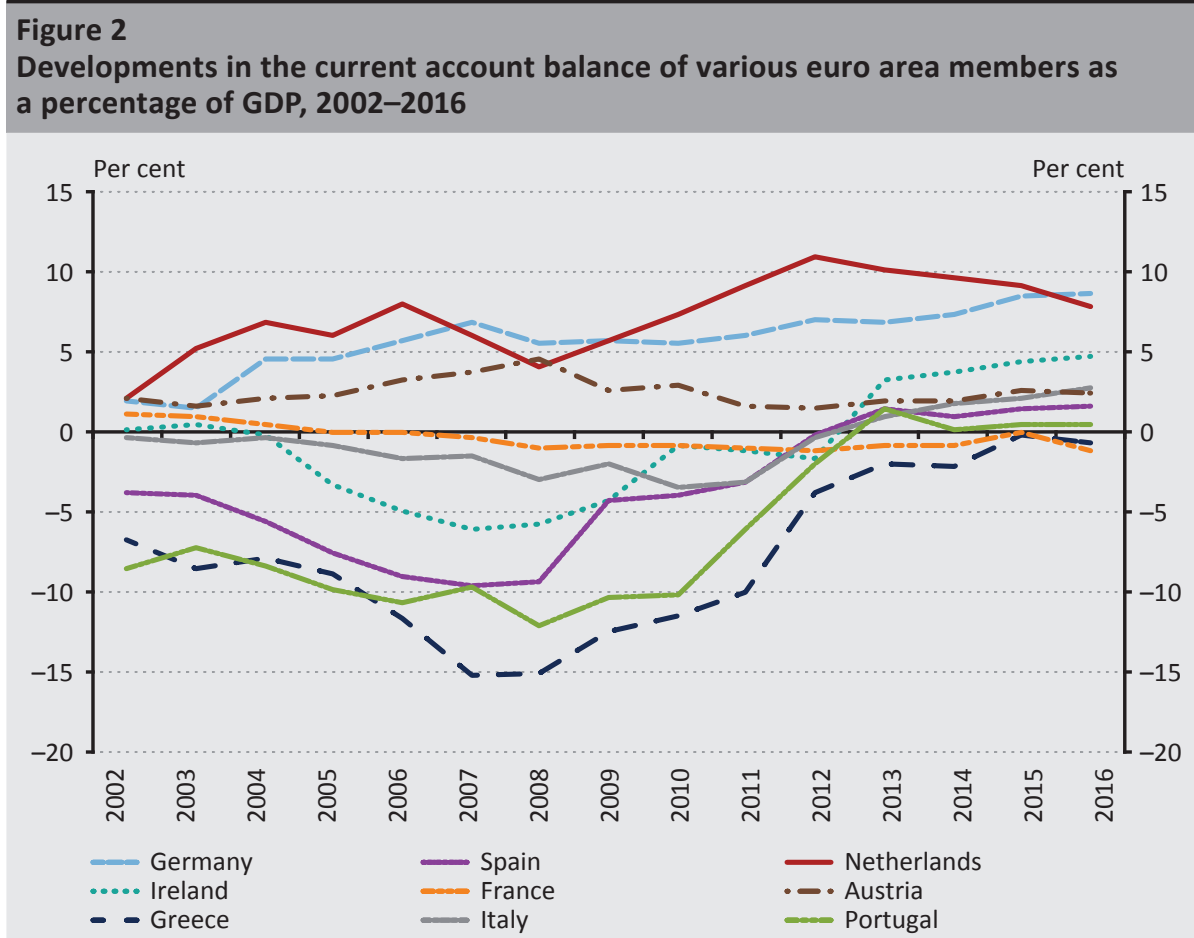

Source: Edited based on Eurostat, World Bank and Trading Economics data. 2016 data of the Netherlands and Austria only for the first three quarters. http://ec.europa.eu/eurostat/web/products-datasets/-/tipsbp20; http://data.worldbank.org/indicator/BN.CAB.XOKA.GD.ZS?year_high_desc=false, http://www.tradingeconomics.com. Downloaded: 18 September 2016 and 15 March 2017.

financial markets (Darvas 2013; De Grauwe 2013). ${ }^{11}$ The fragmentation of the financial market, the scaling down of internal market debtor-creditor relationships, and the stronger home bias can still be observed (Acharya et al. 2014). We can also see this in Figure 1. Despite the fact that we linked the crisis directly to excessive internal capital flows, fragmentation is also an issue. Because one of the channels of alternative adjustment is the mobility of capital, the low level of willingness to invest by non-residents compared to the past may also be the underlying reason for the protracted recovery in the area. ${ }^{12}$ In addition to this, we must also analyse the other mechanisms of market adjustment: the question is to what extent they played a role, in that the imbalances within the current accounts have declined in number by now.

\footnotetext{
${ }^{11}$ This acute problem was finally resolved by the announcement of ECB's OMT program in the fall of 2012 as part of which the European Central Bank committed to the theoretically unlimited purchase of debt securities of the states in difficulty (Pisani-Ferry 2012; De Grauwe 2013).

12 The euro crisis highlights that the capital mobility/financial market integration criteria of the OCA must mostly signify the flexibility of working capital (foreign direct investments).
} 


\section{Market adjustment mechanisms and real heterogeneity in the euro area}

Figure 2 shows that the current account position of the periphery economies closed by 2015-2016 or in certain cases changed to a surplus. The substantial volume of assets held by Germany and the Netherlands remained unchanged in the meantime; moreover, Germany's assets have even increased since 2010. This pattern only partially corresponds to what we expect when market adjustment works properly. As a reminder: if the downturn in one specific region is stronger than in the others, the adjustment mechanisms will cause the export of the weaker performing economy to become relatively more competitive within the euro area. This represents a shift towards financing capacity and, on macro level, it helps deleveraging. But the process corresponding to this also creates the reflection: once competitiveness shifts within the area, the other economies must show a decreasing balance all other things being equal (ceteris paribus). The "ceteris paribus" condition is essential because economic relations outside of the currency union may possibly influence the overall balance in another direction. But this is rather just a dummy obstacle in the perception of change directions. If the products of the originally recessive economy become more competitive than those of euro area members, this is reflected not only in the internal, but also concurrently in the external connections. For this very reason, the contents shown in Figure 2 do not convince us that the EMU could rely on unimpaired adjustment mechanisms. In addition, the closing of the current position at the periphery does not cause debt to contract materially, not even at a macro level for the time being. The balance sheets of the banks of peripheral countries, and lately especially those of Italian banks, continue to show outstandingly high volumes of non-performing loans (Laurent 2017). It seems likely that the mostly 5-15 per cent current account deficits until 2010 "melted away" not because of income generating export expansions, but due to the forced and rapid decrease of imports. We receive differing data about the economic performance of the members, which may once again face the single monetary policy with dilemma after the symmetrical position stemming from the contagion of the crisis (see Eichengreen 2009).

This article tests the observation suggesting the weakness of the adjustment based on several aspects, taking the OCA criteria as basis. The objective is not to discuss the conditions one by one in detail, but to identify the correlations among them so that we can obtain a picture of the resistance to the endogenous spiral.

\subsection{Flexibility of prices and wages}

Based on the analysis of the European Commission (Dhyne et al. 2009), the price level of the euro area was overall rather inflexible before the crisis. The authors 
examined the frequency of consumer price changes in comparison with the USA.$^{13}$ According to the results, consumer prices changed on average annually in the EMU. In 2009, the share of monthly price changes was 15 per cent in the euro area, while in the USA, the same was materially higher: 25 per cent. Consumer markdowns were more frequent in the United States, while in the EMU the retail sector introduced significant inflexibility into price levels by comparison with producer prices. Dhyne et al. (2009) revealed more significant differences in the behaviour of prices among various product categories than among the Member States. Based on this, the relative inelasticity of the price level characterised members more or less to the same extent, with a symmetrical pattern among product categories. Services always showed negligible repricing frequency, while the prices of unprocessed food were the most volatile, apart from energy prices. As part of services, the share of monthly price changes in 2009 was only 5.6 per cent, but that of unprocessed food was 28.3 per cent. In the same year, services represented 47.5 per cent of the euro area's consumption expenditure based on Eurostat data. ${ }^{14}$ Thus, the prices of goods consumed at the highest rate proved to be the most inflexible.

According to the survey, changes included the same proportion of downward price drifts and price increases. This bears significance because in the appropriate reflection adjustment both directions may become necessary. The same must be examined for wages. Prior to the crisis, notable asymmetrical wage developments happened in the euro area. In the periphery countries, the period of growth financed from loans coincided with a significant wage increase period. The growth rate of nominal wages exceeded productivity, while in Germany wages increased to a lesser extent than productivity (Schmidt - Weigert 2013; Hankel et al. 2010). In other words, wages proved to be flexible in the periphery countries, while less so in the centre (although wage growth could have been considered, which has fewer obstacles in principle compared to the reverse direction).

Figure 3 shows wage dynamics, while Figure 4 illustrates the developments in consumer price levels after April 2010 in the periphery countries and in the central countries. It can be concluded from the Figures that since 2010, Greece, Spain, Portugal and partly Ireland performed an overall substantial internal devaluation. The gross average wage was decreasing at least temporarily in each of the periphery states until 2015. A sustained, large-scale contraction only occurred in Greece,

\footnotetext{
${ }^{13}$ Comparison with the United States, a currency union also wide-spread and heterogeneous from many aspects, is rather obvious. We have already discussed in the foregoing the differences in terms of schemes and institutions to be considered when making the comparison. In the sections below, the comparison will be performed based on some real economics and market adjustment aspects.

${ }^{14}$ I performed the calculation based on the database of Eurostat titled "Final consumption expenditure of households by consumption purpose", http://appsso.eurostat.ec.europa.eu/nui/show.do?dataset=nama_ co3_c\&lang=en. Downloaded: 22 February 2017.
} 


\section{Figure 3 \\ Developments in gross average wage in the central and periphery countries, 2001- 2015, YoY, change expressed as a percentage}

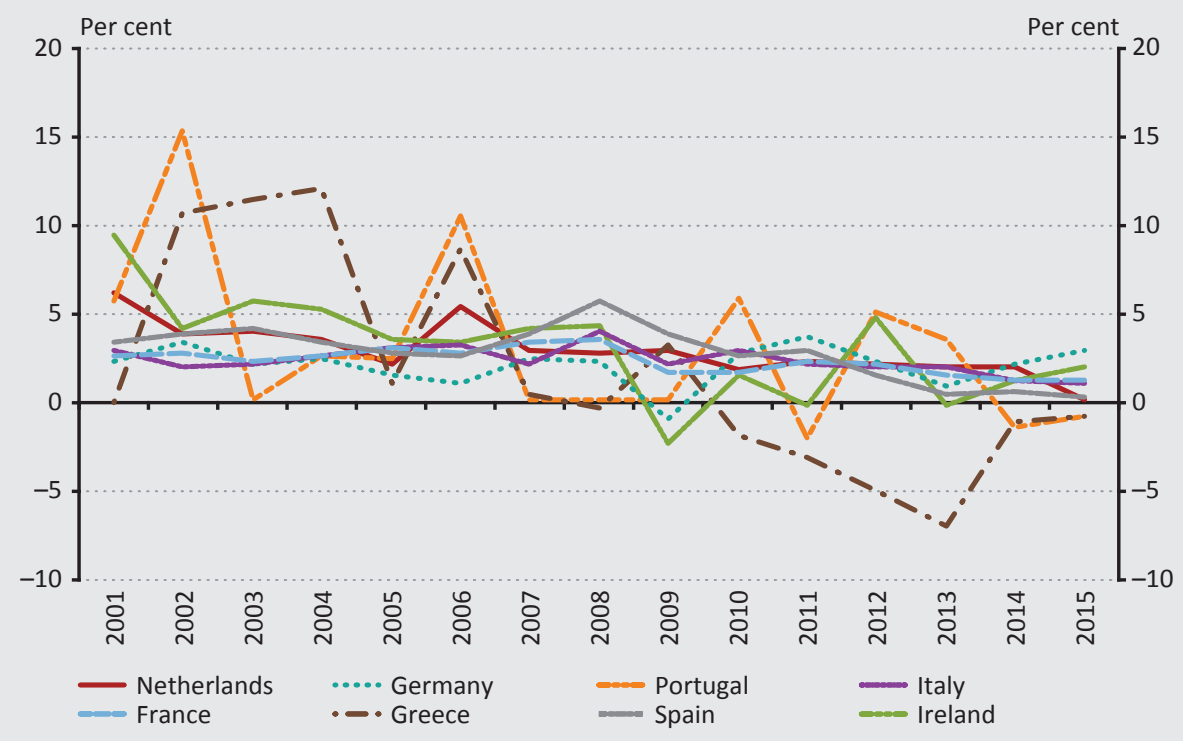

Source: Calculated based on Eurostat data: "Annual net earnings [earn_nt_net]-gross earnings", http:// appsso.eurostat.ec.europa.eu/nui/show.do?wai=true\&dataset=earn_nt_net. Downloaded: 18 March 2017.

where the gross average wage decreased by an average 3.16 per cent per year between 2009 and 2015, while the maximum annual decrease exceeded even 7 per cent. However, in the public sphere, every concerned state performed wage cuts, and in addition, the amount of pensions and various budgetary benefits also shrank (see i.e. Krugman 2011; Skouras 2013; León - Pavolini - Guillén 2015).

In the economies of the central countries, such as the Netherlands and Germany, we observed a change of a more moderate pace compared to the periphery countries since the outbreak of the crisis. Between 2009 and 2015, gross average wage increased by an average of 2.5 per cent per year in Germany and by 1.7 per cent in the Netherlands. This may partly indicate a less flexible wage level, since both economies had some expansion periods during the given period (see Figure 9). We observed wage adjustment in the data of the last two years for Germany entailed by economic growth.

Similarly, the change of price level primarily affected the periphery countries. According to Figure 4, prices decreased for an extended period in Greece, Spain and, to a lesser extent, in Ireland, Portugal and Italy. In the meantime, price levels evolved in a relatively stable manner in Germany and the Netherlands. The GDP growth of the past 2 to 3 years in excess of the euro area average started to bring 


\section{Figure 4}

Monthly average change of consumer prices in $\mathbf{2 0 1 0}$ in the central countries and in the periphery countries

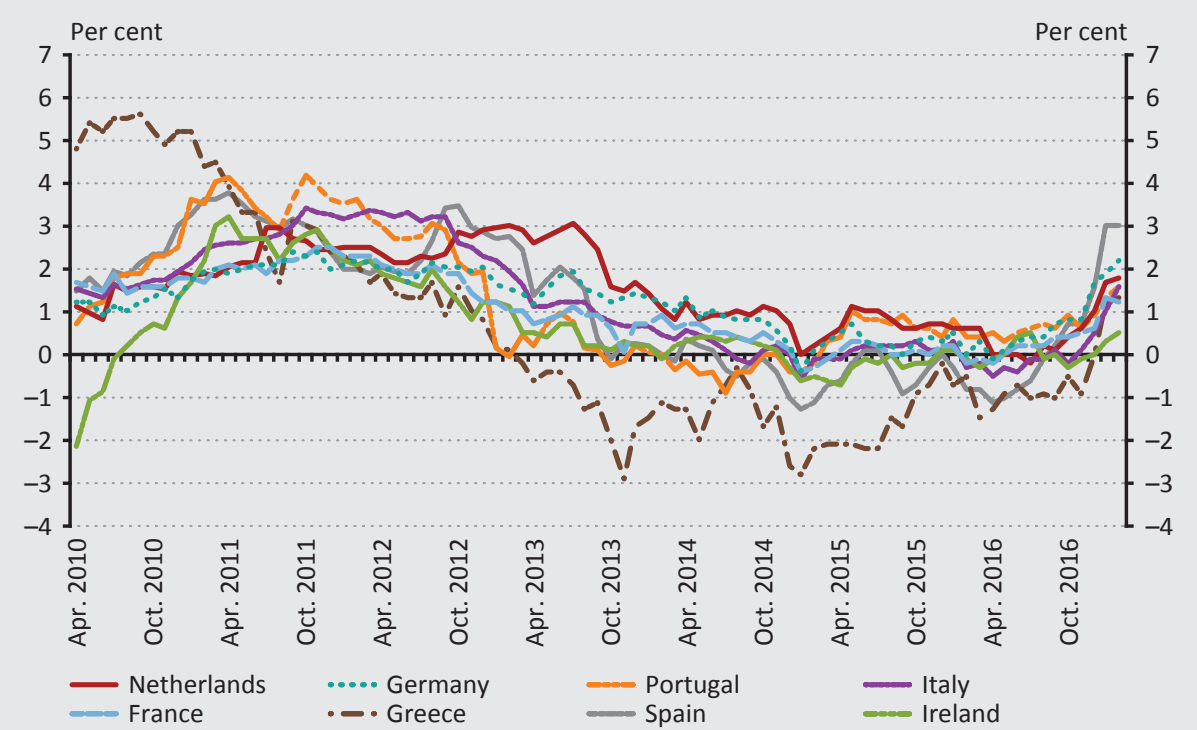

Source: Edited based on the data of Trading Economics. www.tradingeconomics.com. Downloaded: 16 March 2017.

about a more substantial price increase in these economies from the second half of 2016. Meanwhile, the period of internal devaluation seems to be ending in the periphery countries: in the last months of 2016, price levels increased and the average wage remained at the same level also in Greece, Spain and Italy.

We can have only one conclusion and especially one question based on the foregoing. The conclusion is that internal price and wage adjustments unavoidable in single currency areas in the lack of other means are also achieved to a certain extent in the EMU. In the light of the preceding imbalances (excessive indebtedness), it is not surprising that in the periphery countries purchasing power, and in turn, prices and wages also declined due to diminishing borrowing opportunities and the burdens associated with balance adjustment. But the adjustment process is rather unilateral; the expenditures of central countries could not really support its efficiency because wages and prices in these countries shifted relatively to a lesser extent (they increased less). It is difficult to draw a stronger conclusion for the resilience of price and wage levels, because as a result of debtor-creditor inter-linkages the crisis also spilled over to the central countries; therefore, it is not possible to examine the proper reflection adjustment (positive and negative branch). The upcoming period may be decisive in terms of whether prices and wages will evolve in a flexible way in Germany and the Netherlands, two countries about 
to enter economic recovery, enabling the complete unravelling of the effect of the southern internal devaluation. But here the question comes up: can the internal devaluation of the periphery countries be really effective in the EMU? We can give a definite answer based on the following OCA criteria.

\subsection{Product market integration}

Because price and wage adjustment can only work properly in a closely integrated internal market and alongside the mutual competitiveness of products, we must examine the likelihood of lower prices resulting in substantial export performance for the periphery countries that are making the adjustment sacrifice. We can directly ask the question as to what results did the internal devaluation discussed in the foregoing have so far.

Starting from the period prior to 2010 , we can conclude that the euro area is overall an integrated product market region in which trade among members has a longstanding history. The internal trade in goods and services amounted to 50 per cent of the total annual export of the $€ 16$ group on average between 1998 and $2008 .{ }^{15}$ Thus, members were just as open towards one another as towards the rest of the world (from the perspective of export). Figure 5 shows that trade was continuously increasing among the $€ 19$ economies starting from the early 2000 's.

However, there are material differences in the significance of trade in the euro area: some members were relatively more isolated. The value of external trade in the area as a percentage of GDP even in the case of Portugal, Spain, Italy and France was approximately 15 per cent lower than the German value, and was markedly below the values of the Benelux states and Austria in terms of the 1999-2011 average (ECB 2013). Moreover, a shift in emphasis took place towards "non-tradable" goods in the Mediterranean countries (Schmidt - Weigert 2013), as we have already discussed in connection with the housing loan boom (henceforth see Part 3.3).

Based on the experiences so far, the crisis seems to weaken the tightness of internal trade relations. According to Figure 5, the level of trade among members stagnated between 2010 and 2015 while the euro area started to rapidly expand its external exports. Even according to the latest data, extra-EMU exports are expanding: in 2016, they exceeded the level of 2010 by 18 per cent. By comparison: exports between members was 5.6 per cent higher at the same point in time. The level of internal exports showed a minor increase for the first time in 2015. This does not corroborate that the price and wage cuts in the periphery countries would have generated internal export surplus (improvement in competitiveness).

\footnotetext{
${ }^{15}$ Not including the three Baltic EMU Member States, calculated based on the data of Hankel et al. (2010).
} 


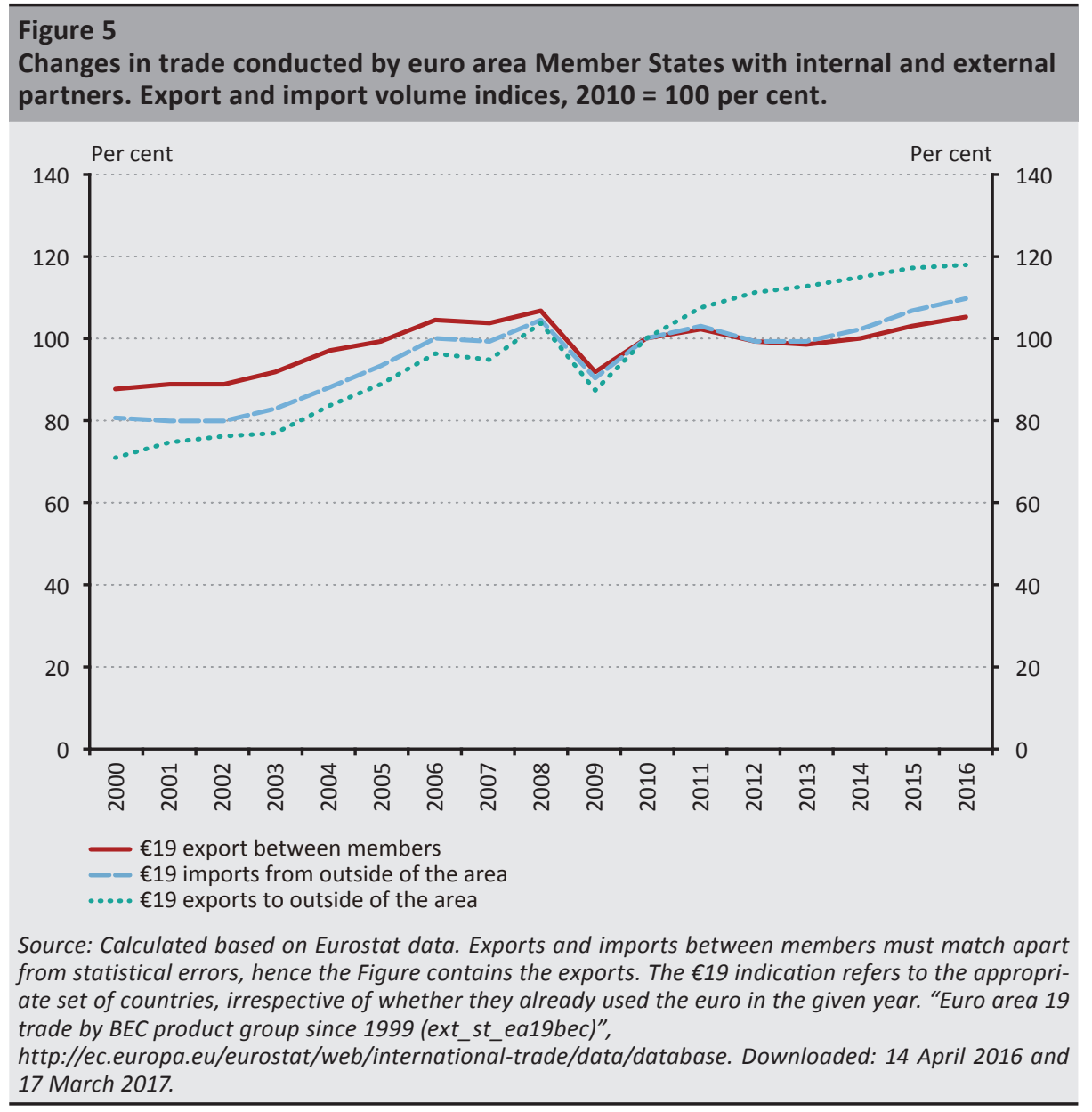

Figure 6 and the data series of the members' exports outside the monetary union is very telling. Figure 6 illustrates the changes in the partner composition of German imports. Since 1998, periphery countries have been selling products and services to Germany in an unchanged proportion. For Italy and Ireland, a continuous slow contraction can be observed. Meanwhile, even economies that are not part of the currency area were able to increase their share on the German import market; thus, we cannot explain their advantage with the elimination of transaction costs and exchange rate risk. Certain Central and Eastern European states obtained an increasing share and China became a key import partner.

Because periphery states were unable to increase their share of exports to the largest economy of the euro area, despite the recent price reductions, the prospect of the expected competitiveness adjustment seems limited. According to the international trade database of Eurostat, the increase in the global exports of the 
$€ 19$ countries cannot be linked to the Mediterranean countries, either. The 2010 level of exports to outside the EMU could not be reached by Spain and Portugal until 2014, by Greece until 2015 and by Italy until the end of $2016 .{ }^{16}$ Of the Member States in the epicentre of the euro crisis only Ireland and most recently Spain and Portugal contributed in merit to the increase in external export. World market exports show a rather diverging pattern in the zone for the time being, underpinning the assumption that the crisis might have impaired the integrity of the product market in the zone. ${ }^{17}$ Based on the data, the current account balance of periphery countries was essentially driven by the drop in imports and not by the increase in exports. If no change happens in that respect, we should expect a delay in the shedding of outstanding debt. ${ }^{18}$

\section{Figure 6 \\ Changes in the composition of German imports by trading counterparties. Share of counterparties, \%, 1998-2015.}

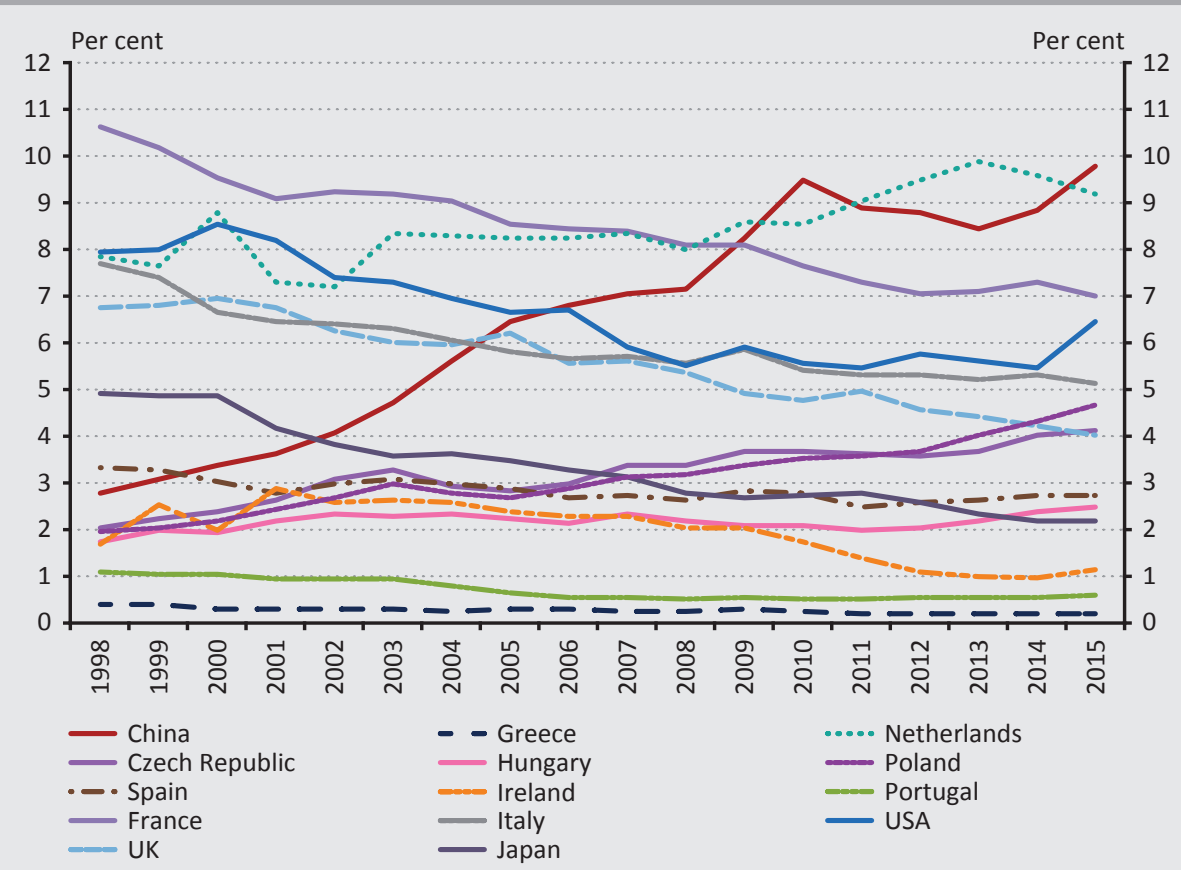

Source: Edited based on the data of World Bank. http://wits.worldbank.org/. Downloaded: 16 March 2017.

${ }^{16}$ Calculated based on Eurostat International Trade Database, "Euro area 19 international trade - monthly data (ei_etea19_m)" (export volume indices, 2010 = 100 per cent, seasonally and work day effect adjusted data). http://appsso.eurostat.ec.europa.eu/nui/show.do?dataset=ei_etea19_m\&lang=en Downloaded: 18 March 2017.

${ }^{17}$ Together with Germany, the Netherlands, Slovakia and Slovenia also boast of fast external export expansion compared to 2010.

${ }^{18}$ As set out above, based on its current position, Spain seems to be an exception, where the data already indicate substantial external export growth. But shedding liabilities is obviously not a simple task even when coupled with growing financing capacity, because - as discussed in Part 1 - the export revenues of the various economic players are not directly available for the deleveraging of other players. 


\subsection{Similarities and diversification of economic structures}

EMU economies can be essentially considered diversified, none of the members are characterised by an extreme exposure to partial shocks. This is suggested by the fact that trade within the zone is mainly conducted between industries, which was also facilitated by the rise in internal trade prior to the crisis, because most of the members were expanding the scope of their export goods at that time (ECB 2013).

However, some previously present differences preserved during the crisis can also be observed. These differences may cause problems in the operation of the adjustment mechanisms, and as such, in the degree of price elasticity and export competitiveness and also in labour mobility. In Germany, manufacturing has a relatively higher share than services, and according to the data publications of the Eurostat, its share within added value remained stable despite the decline in global demand. Between 2008 and 2013, this share exceeded the internal contribution of manufacturing in Mediterranean economies by 13 percentage points in each of these years. At the same time, in Greece, Portugal and Spain, trade, construction industry and services, that is, practically non-tradable goods were relatively dominant. Compared to the structural stability of the German economy, we can observe a more significant structural realignment between 2008 and 2013 in these countries, because, for example, the bursting of the real estate bubble in Spain setback the share of the construction industry's added value by 10 percentage points. But a radical structural change or a shift towards manufacturing failed to take place. So the most relevant structural differences are manifested in that central countries primarily operate a knowledge and capital intensive economy, while the southern periphery countries' economies are more labour intensive.

In terms of market adjustment, several possible obstacles can be identified here. On the one hand, as discussed in the foregoing, prices of the service sector are usually less flexible. During the $\mathbf{2 0 1 0}$ crisis, this disadvantage was only partially present, because compared to other factors, the price adjustment of periphery countries was not negligible. On the other hand, it is also true for service sectors even in modern economies that the value generated by these sectors does not lend itself as much to export. These sectoral proportions may have played the role in that periphery countries were unable to increase their exports despite the price level reduction. Although the role of tourism-related export revenues is outstanding in these economies - as demonstrated by the third quarter surpluses shown in the quarterly current accounts statistics -, these are not necessarily sufficient to create a real effect for internal devaluation. At the same time, Germany's extensive manufacturer capacities are immanently prone to generate sustained surplus, which is due, inter alia, to the economic interest linked to uninterrupted production (see EC 2016). The different focus is also apparent in the labour force base of the two zones, so mobility is hindered by the differences in qualification and skills. Even 
with adequate migration willingness, it remains uncertain whether a manufacturing entity on an upswing needs the same amount of additional labour as the number of workers left unemployed in an economy sinking into recession (or vice versa).

\subsection{Labour mobility}

Labour mobility can be efficiently captured through the analysis of the distribution of unemployment rates, since any sustained difference suggests that the shocks affecting the regions cannot disappear through the flow of labour force (see for example Eichengreen et al. 1990). Figure 7 shows developments in the deviation of unemployment rates between 2001-2016 for the $€ 12$ and $€ 19$ country groups and, by comparison, for the states of the USA.

\section{Figure 7}

Deviation of unemployment rates in the euro area and the USA, 2001-2016

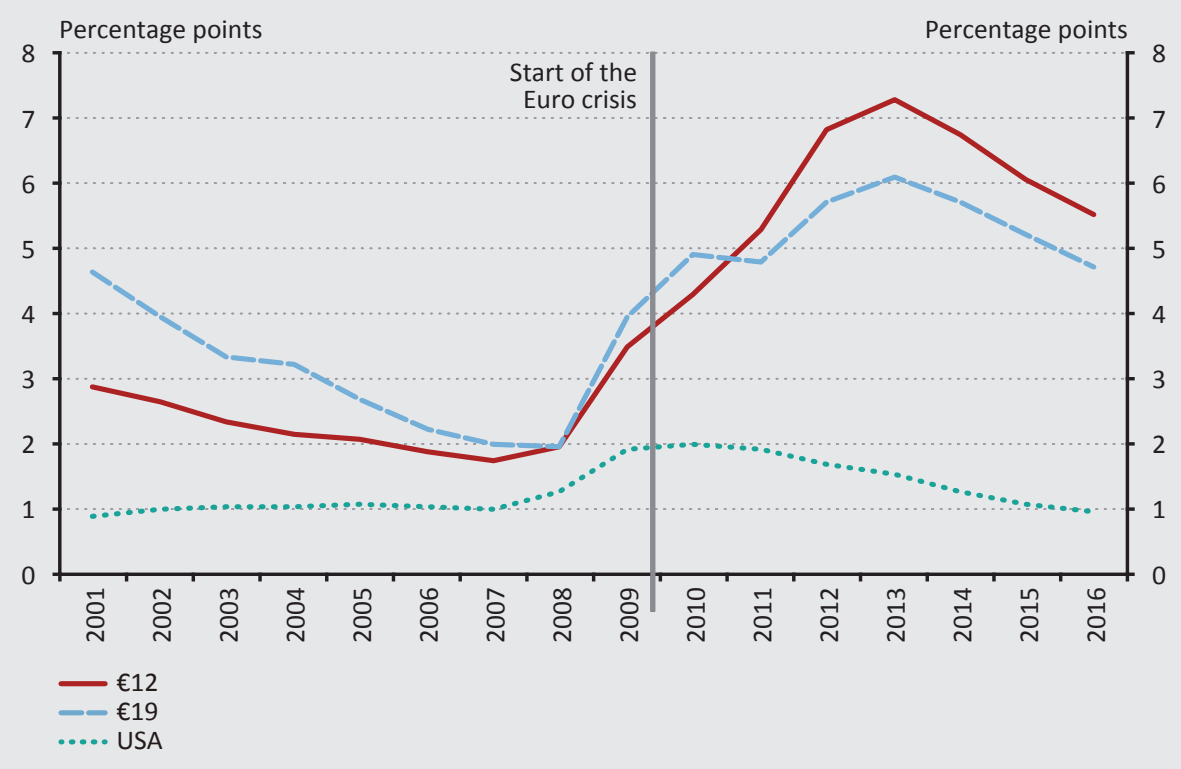

Note: The $€ 12$ and $€ 19$ indications refer to the appropriate set of countries, irrespective of whether they already used the euro in the given year.

Source: Calculated based on the data of Eurostat publication "Unemployment rate, annual average" and Bureau of Labour Statistics, "Unemployment Rates for States. Annual Average Rankings". http://www. bls.gov/lau/lastrk13.htm.

http://appsso.eurostat.ec.europa.eu/nui/show.do?dataset=une_rt_a\&lang=en. Downloaded: 09 April 2016 and 17 March 2017.

In the euro area, the unemployment rates of the Member States had been already significantly different for a sustained period before the crisis compared to the USA. This difference was gradually decreasing until 2008, but primarily within the broader group containing 19 countries, where the contraction on the deviation is mainly 
attributable to the rapid decline in unemployment in the three Baltic states. The difference between the $€ 12$ countries started from a lower level, but dropped less steeply until 2008 , i.e. the average value remained relatively more stable in this narrower circle.

It is worthy of attention that the global crisis originating from the USA brought about only a slight divergence in the state-level unemployment data in the United States of America itself and any substantial increase in deviation was only observed for a period of two years. Thereafter, the increased deviation disappeared over a period of 5 years: In 2015-2016, a stable 1 percentage point average divergence, already seen prior to the crisis, can be observed. By contrast, from 2008 and from the time the crises reached the euro area, these rates suddenly started to drift apart. Divergence increased all the way until 2013. Over the past three years, these differences decreased by approximately 0.5 percentage points each year, but the $€ 19$ block is still approximately 3 percentage points away from the starting value.

The divergence was stronger within the $€ 12$ group compared with the group of the 19 member states. This phenomenon is in line with the above finding, according to which unemployment rates of the 12 countries were converging at a slower pace. This highlights the source of tension between the central and periphery countries since Greece, Spain, Italy, Ireland and Portugal, considered to be the centre of the crisis, are all part of the $€ 12$ group, together with Germany.

The decline in deviation over the past three years suggests a certain mobilisation of the labour force. The labour force statistics published by the Member States are unfortunately too narrow to form a dynamic picture of the distribution of migrant workers by place of birth. In the meantime, the issue of the labour shortage experienced in the German economy arises from time to time (Eichhorst et al. 2013; BMWFW 2013; EP 2015). This phenomenon is hardly consistent with the high unemployment rates of the periphery countries, especially with the outstandingly high youth unemployment analysed on a number of occasions, that is, it definitely implies some mobility issues. The young employee group must be highlighted because a greater geographic and occupational mobility is expected from them. Klekowski von Koppenfels - Höhne (2017) give accounts of the increasing employment in Germany of workers coming from Southern Europe, especially the young and skilled ones. This correlates with the MobilPro EU programme launched by the German government in 2013 which intended to connect the needs of young unemployed workers of Southern Europe with the need of the German economy for skilled workers. But according to the authors, the share of employment in Germany of Southern European workers cannot be accurately determined. 
Figure 8 illustrates developments in youth unemployment rates in the $€ 12$ countries and in the United States. The European data were available for the age group between 20 to 24 years while the US data were available for the age group between 25 to 34 years, measuring the share of unemployed persons against the active population of the appropriate age in both cases. The EMU values are shown by Member State, while for US states, the value of minimum and maximum rates is shown for each year. Based on this, we can compare the range of deviation and the dynamics occurred during the crisis. Our findings here are similar to those made for Figure 7. In the United States, we observe a smaller difference between the minimum and the maximum rates prior to the crisis, which is approximately $4-5$ percentage points. This is one third of the 15 percentage points difference observed

\section{Figure 8 \\ Developments in youth unemployment rates in the $€ 12$ countries and in the states of the USA}
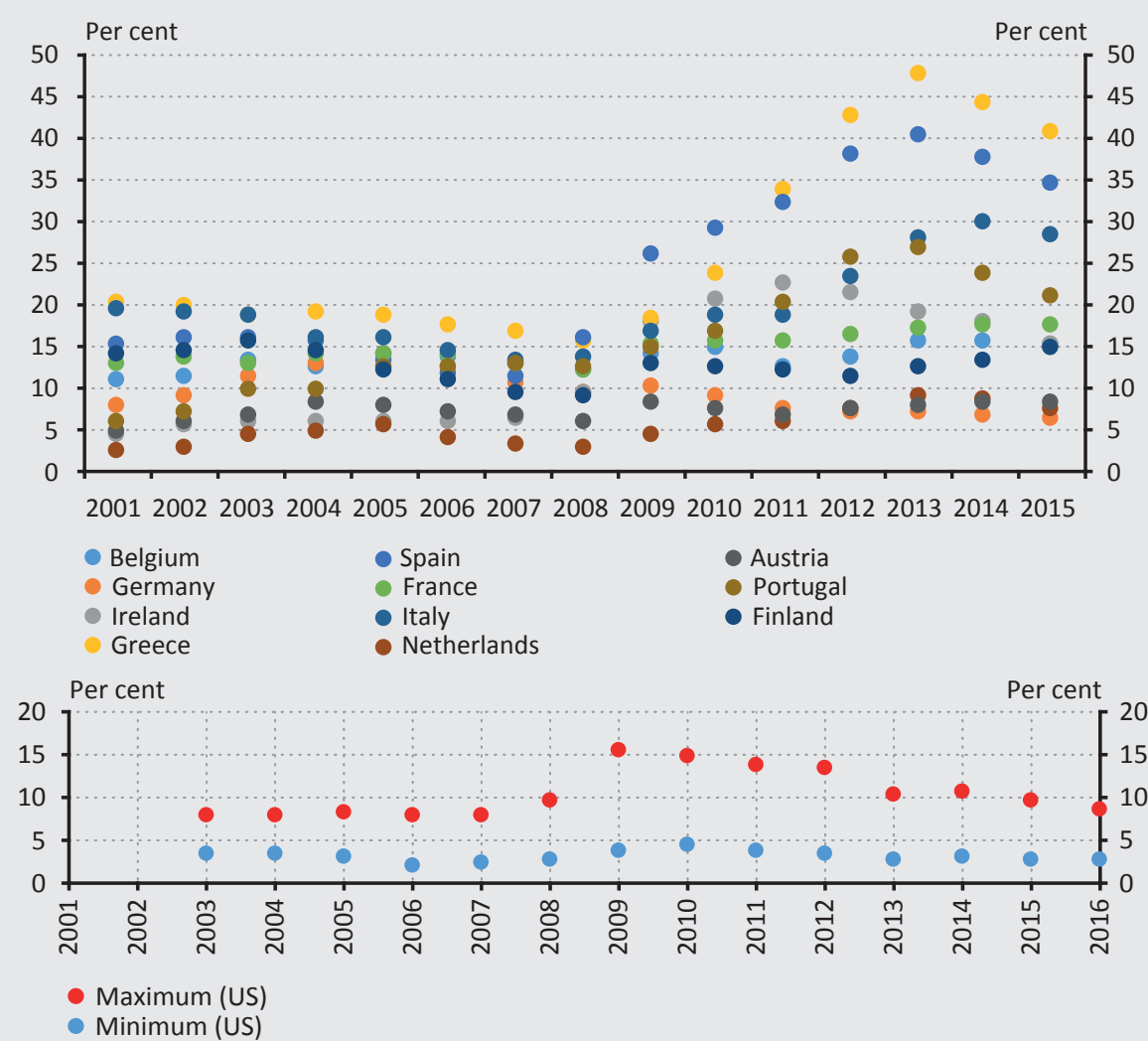

Source: Edited based on the data of Eurostat and the Bureau of Labour Statistics. $€ 12$ data pertain to the active population between the ages of 20-24, while US data refer to the active population between the ages of 25-34. "Youth unemployment by sex, age and educational attainment level [yth_empl_090]", https://www.bls.gov/lau/ex14tables.htm. Downloaded: 17 March 2017. 
in the $€ 12$. (It is interesting to note that regional differences are systematically higher in the unemployment data of the young age groups compared to the figures available for the total active population both in the USA and in the EU.) As a result of the crisis, we can observe a minor, short divergence in the United States while in the $€ 12$ block, deviation remained substantial even after 2008-2010. 2013 seems to be a turning point in that case as well. The range started to narrow since then, although it still remains expressly broad: it is over 30 percentage points. The same countries keep the minimum and maximum values with some slight changes since the start of the time series: the lowest rates are associated with the Netherlands, Germany and Austria (central countries) while the highest rates can be linked to Greece and Spain (periphery countries). This constancy suggests that there are some inherent problems also in terms of labour force mobility in this group of countries. But based on recent developments and government measures taken during the past few years, change is not impossible in the case of skilled employees. However, expectations regarding qualifications and expertise call attention to the fact that differences in the economic structure discussed in Part 3.3 represent a real obstacle and there are also some language and language knowledge related issues.

\subsection{Business cycles}

We have already talked about the diverging economic performance of EMU Member States. As a closure of the analysis, Figure 9 shows the developments in GDP between 2007 and 2016. This picture shows relatively similar patterns of booms and busts for the Member States which is the consequence of a general product market integrity and relative structural similarity in the real economy, while from the monetary aspect, it is the consequence of a close interlocking of financial markets. Thus, the members move more or less together in their directions, but the delays compared to one another and the differences in scale may face the monetary policy with some constant optimisation issues. De Grauwe (2012a:175) illustrates this with the example of the 2008 downturn: according to his estimation, at that point in time the zone as a whole did not differ from the potential output, "so there was nothing to adjust". However, as we can see in the Figure, the current annual growth of specific countries varied in a range of 4 percentage points, producing both decline and growth in GDP, therefore the difference was substantial between the individual output gaps. Individual members certainly had different monetary policy needs.

At present, a situation is emerging where the economies may demonstrate heterogeneous growth over the medium term, and as a result, inflationary outcomes may also substantially differ. The most recent data as of the end of 2016 currently signal the end of the deflationary period, but the risk of inflation is uneven throughout the zone. From the perspective of the members showing more fragile economic performance and leaving deflation behind, the professional opinion 
regarding the necessity of an interest rate increase may be completely different than in the case of those members that have a considerably more favourable outlook for economic activity. In that regard, the world market connections presented in Part 3.2 play a special role, because the economies that are (also) externally oriented may pick up momentum more easily from the expected growth of external partners (see IMF 2017).

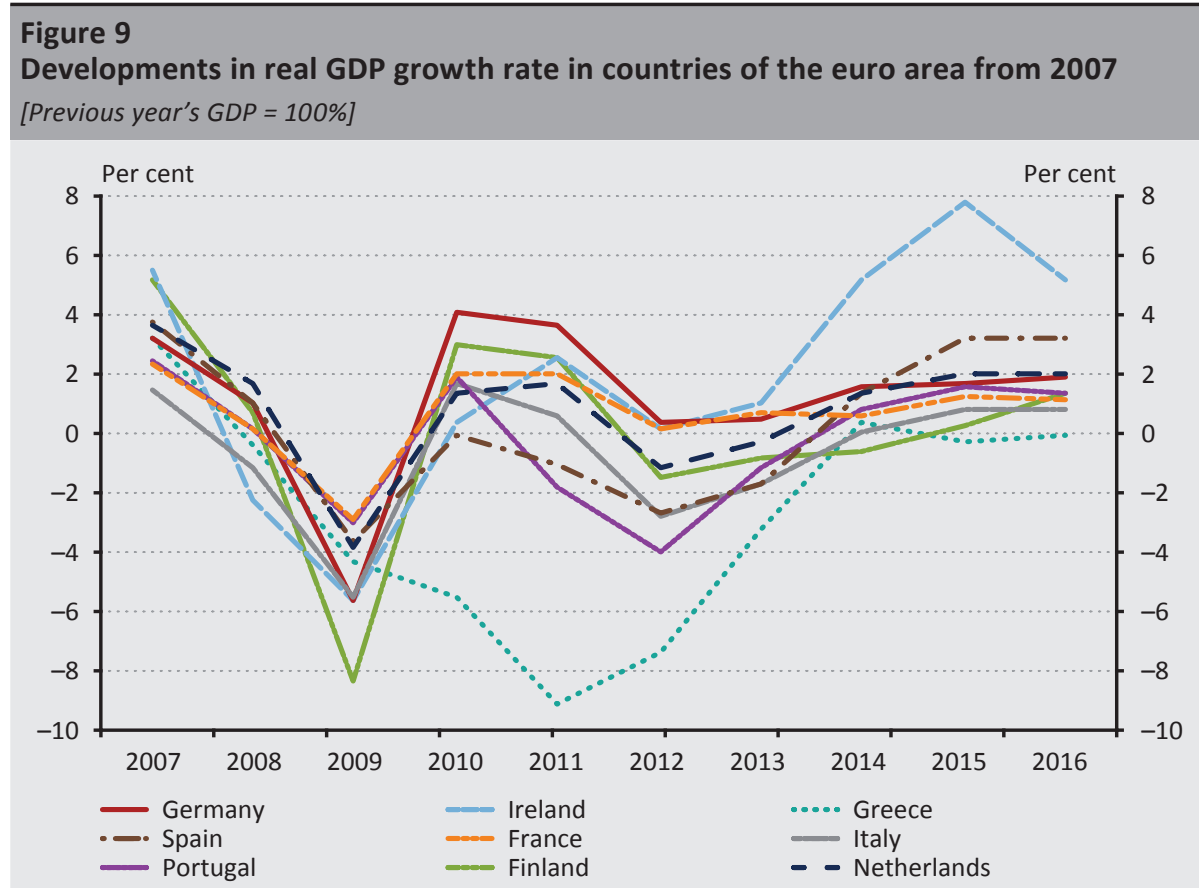

Source: Edited based on Eurostat data: http://ec.europa.eu/eurostat/web/products-datasets/-/ tec00115. Downloaded: 16 April 2016 and 17 March 2017.

\section{Summary of conclusions}

This article examined the endogenous disturbances of the single currency area and the background of the euro crisis as well as the prospects of market adjustment. Currency zones always carry the risk that the common (single) monetary policy is unable to meet the simultaneous needs of the regions. In that case, endogenous feedbacks are generated in the system that may entail inflationary, financial stability and real economy related problems. This mechanism played a role in the developments in the euro crisis because after the introduction of the single currency, interest rates evened out at a low level, which encouraged debt overhang 
and asset price bubbles in the periphery countries. Deepening financial integration was accompanied by the "efficient" dissemination of vulnerabilities as these were increasingly shifted inward, creating unsustainable exposures for both the central and the periphery countries (both in gross and net terms). EMU's institutional system was unprepared for the early identification of private indebtedness and the mitigation of systemic risks and was also partly unprepared for the management of public debt. The lack of clarity of the crisis management and risk community framework resulted in a confidence crisis in the markets at the most critical moments.

But when we are missing risk monitoring, economic policy coordination and crisis management systems, we must also ask the question as to what fundamentally drives economic disturbances and/or what may prevent their self-adjustment. This is relevant irrespective of the degree to which we consider market efficiency as being valid, because there is no guarantee for the absolute power of institutions. Even a properly operating institutional system is not supposed to handle repeated severe tensions. From the perspective of real economy, EMU shows a mixed picture based on the experiences gained so far. Generally speaking, a region having an integrated product market and exhibiting interconnectivity in many areas has a rational need for a common currency. However, the centre-periphery fault-line may force the members over the medium term to draw the balance of belonging to the euro area. After the 2010 crisis, the relative internal price and wage adjustments entailed economic sacrifices for the periphery countries, but based on the foregoing, it proved to be less efficient as it failed to meet its essential objective to date, i.e., the expansion of exports. This can be explained by complex competitiveness issues. Moreover, no fast labour market adjustment took place either. The partial results primarily affect employees with a higher qualification, but youth unemployment remains overall an acute problem. To achieve the long-term functioning of the euro, and what is more, to actually realise the desired benefits, a comprehensive, targeted structural, competitiveness and regional policy framework and the harmonisation of initiatives are needed, which can ensure the improvement of internal adjustment mechanisms within the area. 


\section{References}

Ábel, I. - Lehmann, K. - Tapaszti, A. (2016): A pénz és a bankok ellentmondásos kezelése a makroökonómiában (The controversial treatment of money and banks in macroeconomics). Hitelintézeti Szemle (Financial and Economic Review) Volume 15, Issue 2, June, pp. 33-58.

Acharya, V. - Drechsler, I. - Schnabl, P. (2014): A Pyrrhic Victory? Bank Bailouts and Sovereign Credit Risk. The Journal of Finance, Vol. 69, No. 6, December: 2689-2739. https://doi. org/10.1111/jofi.12206.

Baldwin, R. - Beck, T. - Bénassy-Quéré, A. - Blanchard, O. - Corsetti, G. - De Grauwe, P. - den Haan, W. - Giavazzi, F. - Gros, D. - Kalemli-Ozcan, S. - Micossi, S. - Papaioannou, E. - Pesenti, P. - Pissarides, C. - Tabellini, G. - Weder di Mauro, B. (2015): Rebooting the Eurozone. Step I. Agreeing on a Crisis Narrative. CEPR Policy Insight, No. 85 (November). http://voxeu.org/sites/default/files/file/Policy\%20Insight\%2085.pdf. Downloaded: 1 February 2016

Bayoumi, T. - Eichengreen, B. (1997): Ever Closer to Heaven? An Optimum-Currency-Area Index for European Countries. European Economic Review, Vol. 41., No. 3-5: 761-770. https://doi.org/10.1016/S0014-2921(97)00035-4.

Benczes, I. (2014): Az optimális valutaövezetek elmélete: Bevezetés (The theory of optimum currency areas: An introduction). ResearchGate, 2014. November 7. https://www. researchgate.net/publication/267927396_Az_optimalis_valutaovezetek_elmelete_ Bevezetes. Downloaded: 12 March 2017.

Blanchard, O. - Giavazzi, F. (2002): Current Account Deficits in the Euro Area: The End of the Feldstein-Horioka Puzzle? Brookings Papers on Economic Activity, No. 2: 147-186. https:// doi.org/10.1353/eca.2003.0001.

BMWFW (2013): Europe Between Youth Unemployment and Skilled Labour Shortages. Which strategies help to meet companies' skilled labour needs in the future? Bundesministerium für Wissenschaft, Forschung und Wirtschaft, Germany. http://www. bmwi.de/Redaktion/DE/Downloads/J-L/strategiepaier-fachkraeftesicherung-en.pdf? blob=publicationFile\&v=1. Downloaded: 13 November 2016.

Borio, C. - Disyatat, P. (2011): Global Imbalances and the Financial Crisis: Link or No Link? BIS Working Paper, No. 346. http://www.bis.org/publ/work346.pdf. Downloaded: 8 January 2016.

Bracke, T. - Bussiere, M. - Fidora, M. - Straub, R. (2010): A Framework for Assessing Global Imbalances. The World Economy, Vol. 33, No. 9 (September): 1140-1174. 
Cesaratto, S. (2015): Alternative Interpretations of a Stateless Currency Crises. The Italian Association for the Study of Economic Asymmetries, a/simmetrie working paper 2015/08. http://www.asimmetrie.org/wp-content/uploads/2015/08/AISWP201508.pdf. Downloaded: 18 January 2016

Csajbók, A. - Csermely, Á. (editor) (2002): Adopting the Euro on Hungary: Expected Costs, Benefits and Timing. MNB Occasional Papers 24 Magyar Nemzeti Bank (The Central Bank of Hungary), Budapest.

Darvas, Zs. (2013): The Euro Crisis: Ten Roots but Fewer Solutions. In: Farkas, Beáta (editor): The Aftermath of the Global Crisis in the European Union. Cambridge Scholars Publishing, Newcastle upon Tyne. pp. 83-104.

De Grauwe, P. (2012a): Economics of Monetary Union. Oxford University Press, Oxford, 9th edition.

De Grauwe, P. (2012b): The Governance of a Fragile Eurozone. The Australian Economic Review, Vol. 45, No. 3. 255-268. https://doi.org/10.1111/j.1467-8462.2012.00691.x.

De Grauwe, P. (2013): Design Failures in the Eurozone - Can They Be Fixed? European Economy. Economic Papers 491. (April). European Commission Directorate-General for Economic and Financial Affairs, Brussels. http://ec.europa.eu/economy_finance/ publications/economic_paper/2013/pdf/ecp491_en.pdf. Downloaded: 6 March 2016.

De Grauwe, P. - Ji, Y. (2012): TARGET2 as a Scapegoat for German Errors. http://voxeu.org/ article/target2-scapegoat-german-errors. Downloaded: 26 August 2013 and 16 April 2016.

Delors Report (1989). Report on Economic and Monetary Union in the European Community. Committee for the Study of Economic and Monetary Union. Prepared under the guidance of Jacques Delors President of the Commission, 17 April 1989 http://ec.europa.eu/economy_ finance/publications/pages/publication6161_en.pdf. Downloaded: 27 March 2016.

De Sousa, J. (2011): The Currency Union Effect on Trade Is Decreasing Over Time. MPRA Paper No. 40327 (November). Munich Personal RePEc Archive, https://mpra.ub.uni-muenchen. de/40327/1/MPRA_paper_40327.pdf. Downloaded: 15 March 2017.

Dhyne, E. - Konieczny, J. - Rumler, F. - Sevestre, P. (2009): Price Rigidity in the Euro Area An Assessment. European Economy, Economic Papers 380 (May). European Commission, Directorate-General for Economic and Financial Affairs. http://ec.europa.eu/economy_ finance/publications/pages/publication15196_en.pdf. Downloaded: 27 September 2013 and 13 April 2016.

Eichengreen, B. (2009): Was the Euro a Mistake? VOX CEPR's Political Portal, 2009.01.20. http://voxeu.org/article/was-euro-mistake. Downloaded: 2 April 2016. 
Eichengreen, B. - Obstfeld, M. - Spaventa, L. (1990): One Money for Europe? Lessons from the US Currency Union. Economic Policy, Vol. 5, No. 10 (April): 117-187. https://doi. org/10.2307/1344577.

Eichhorst, W. - Hinte, H. - Rinne, U. (2013): Youth Unemployment in Europe: What to Do About It? IZA Policy Paper No. 65 (2013). Institute for the Study of Labour. http://repec. iza.org/pp65.pdf. Downloaded: 12 November 2016.

ECB (2013): Intra-Euro Area Trade Linkages and External Adjustment. ECB Monthly Bulletin, January: 59-74. http://www.ecb.europa.eu/pub/pdf/mobu/mb201301en.pdf. Downloaded: 28 September 2013.

Estrada, Á. - Galí, J. - López-Salido, D. (2013): Patterns of Convergence and Divergence in the Euro Area. IMF Economic Review, Vol. 61, No. 4: 601-630. https://doi.org/10.1057/ imfer.2013.22.

EC (2016): European Commission: Quarterly Report on the Euro Area. European Economy, Institutional Paper, 016 (January). European Commission, Directorate-General for Economic and Financial Affairs.

http://ec.europa.eu/economy_finance/publications/eeip/pdf/ip016_en.pdf. Downloaded: 12 April 2016.

EP (2015): European Parliament: Labour Market Shortages in the European Union. European Parliament, Directorate General for Internal Policies, Policy Department A: Economic And Scientific Policy. Study for the EMPL Committee (March). http://www.europarl.europa. eu/RegData/etudes/STUD/2015/542202/IPOL_STU(2015)542202_EN.pdf Downloaded: 12 November 2016.

Feldstein, M. (1992): The Case Against EMU. The Economist, June 13: 19-22. www.nber. org/feldstein/economistmf.pdf. Downloaded: 8 April 2016.

Frankel, J.A. - Rose, A.K. (1998): The Endogeneity of the Optimum Currency Area Criteria. The Economic Journal, No. 108. (July): 1009-1025. https://doi.org/10.1111/1468-0297.00327.

Frankel, J.A. - Rose, A.K. (2002): An Estimate of the Effect of Common Currencies on Trade and Income. The Quarterly Journal of Economics, Vol. 117, No. 2. (May): 437-466. https:// doi.org/10.1162/003355302753650292.

Giavazzi, F. - Spaventa, L. (2010): Why the Current Account May Matter in a Monetary Union. Lessons from the Financial Crisis in the Euro Area. IGIER Working Paper Series No. 426., 28 December 2010 Innocenzo Gasparini Institute for Economic Research. http://www.igier. unibocconi.it/files/426.pdf. Downloaded: 19 March 2016. 
Godley, W. (1992): Maastricht and All That. London Review of Books, Vol. 14, No. 19. (8 October): 3-4. www.Irb.co.uk/v14/n19/wynne-godley/maastricht-and-all-that. Downloaded: 8 April 2016.

Goodhart, C.A.E. (1998): The Two Concepts of Money: Implications for the Analysis of Optimal Currency Areas. European Journal of Political Economy, Vol. 14 (March): 407-432. http:// dx.doi.org/10.1016/s0176-2680(98)00015-9.

Hale, G. - Obstfeld, M. (2014): The Euro and the Geography of International Debt Flows. Federal Reserve Bank of San Francisco Working Paper Series, 2014-10 (December). http:// www.frbsf.org/economic-research/files/wp2014-10.pdf. Downloaded: 8 January 2016.

Hankel, W.- Hauskrecht, A. - Stuart, B. (2010): The Euro-Project at Risk. ZEl Working Papers, No. B 04. Zentrum für Europäische Integrationsforschung, Universität Bonn.

https://www.econstor.eu/dspace/bitstream/10419/46218/1/638549396.pdf. Downloaded: 24 July 2013.

IMF (2017): World Economic Outlook. January. https://www.imf.org/external/pubs/ft/ weo/2017/update/01/. Downloaded: 19 March 2017.

Ingram, J.C. (1973): The Case for European Monetary Integration. Essays in International Finance, No. 98 (April). https://www.princeton.edu/ ies/IES_Essays/E98.pdf. Downloaded: 8 April 2016.

Kenen, P.B. (1969): The Theory of Optimum Currency Areas: An Eclectic View. In: Mundell, R. - Swoboda, A. (editor): Monetary Problems of the International Economy. University Press of Chicago, Chicago, pp. 41-60.

Kiss, J.L. (2011): Euróválság és intézményi hatalom: változások a német EU-politikában (Euro crisis and institutional power: changes in the German EU policy). Foreign Affairs Review, (spring). http://kki.hu/assets/upload/Kulugyi_Szemle_2011_01_Eurevelseg_ees_ inteezmeenyi.pdf. Downloaded: 15 March 2017.

Klekowski von Koppenfels, A. - Höhne, J. (2017): Gastarbeiter Migration Revisited: Consolidating Germany's Position as an Immigrant Country. In: Lafleur, J. M. - Stanek, M. (2017): South-North Migration of EU Citizens in Times of Crisis. IMISCOE Research Series, Springer Open, Chapter 9, pp. 149-174.

https://link.springer.com/chapter/10.1007/978-3-319-39763-4_9. Downloaded: 18 March 2017.

Krugman, P. - Obstfeld, M. (2003): Gazdaságpolitika és koordináció a lebegő árfolyamok rendszerében; Optimális valutaövezetek és az európai tanulságok (Economic policy and coordination in the system of floating exchange rates; Optimum currency areas and European lessons). In: Krugman, P. - Obstfeld, M.: International economy. Theory and economic policy. Chapters 19-20 Panem Kiadó, Budapest, pp. 642-723. 
Krugman, P. (2011): Can Europe Be Saved? New York Times Magazine, January 16:26. http://www.nytimes.com/2011/01/16/magazine/16Europe-t.html?pagewanted=all. Downloaded: 9 October 2013 and 2 April 2016.

Laurent, L. (2017): Italy's Banking Garage Sale. Bloomberg, March 8. https://www. bloomberg.com/gadfly/articles/2017-03-08/italy-s-banks-are-running-out-of-family-silverto-sell Downloaded: 18 March 2017.

León, M. - Pavolini, E. - Guillén, A.M. (2015): Welfare Rescaling in Italy and Spain: Political Strategies to Deal with Harsh Austerity. European Journal of Social Security, Vol. 17, No. 2: 182-201. https://doi.org/10.1177/138826271501700203.

Magas, I. (2016): Európai Unió: Útelágazás és Brexit-tanulságok (European Union: Intersection and lessons from Brexit). Köz-gazdaság, 11 (3): 43-55. http://unipub.lib.uni-corvinus. hu/2486/1/KG2016n3_Magas.pdf. Downloaded: 1 March 2017.

McKinnon, R.I. (1963): Optimum Currency Areas. The American Economic Review, Vol. 53, No. 4. (September): 717-725.

Micossi, S. (2016): Balance-of-Payments Adjustment in the Eurozone. In: Baldwin, R. Giavazzi, F. (editor): How to Fix Europe's Monetary Union: Views of Leading Economists. CEPR e-book, 2016.02.12: 188-206. http://voxeu.org/content/how-fix-europe-s-monetaryunion-views-leading-economists. Downloaded: 14 March 2016.

Mongelli, F.P. (2013): The Mutating Euro Area Crisis: Is the Balance Between "Sceptics" and "Advocates" Shifting? ECB Occasional Paper No. 144. https://www.econstor.eu/ bitstream/10419/154597/1/ecbop144.pdf. Downloaded: 15 March 2017.

MNB (2011): Elemzés a konvergenciafolyamatokról (Analysis of the convergence process). October. https://www.mnb.hu/letoltes/konvergencia-elemzes-hu.pdf Downloaded: 2 February 2017.

MNB (2014): Growth Report. https://www.mnb.hu/letoltes/honlapra-novekedesi-jelenteshun-201411.pdf. Downloaded: 2 February 2017.

Mundell, R.A. (1961): A Theory of Optimum Currency Areas. The American Economic Review, Vol. 51, No. 4 (September): 657-665.

Neményi, J. - Oblath, G. (2012): Az euró hazai bevezetésének újragondolása (Rethinking the introduction of the euro in Hungary). Occasional papers, MT-DP - 2012/14, Hungarian Academy of Science, Economics and Regional Sciences Research Centre, Economics Institute. http://econ.core.hu/file/download/mtdp/MTDP1214.pdf. Downloaded: 12 March 2017.

Obstfeld, M. (2012a): Does the Current Account Still Matter? NBER Working Papers, No. 17877. National Bureau of Economic Research. https://doi.org/10.3386/w17877. 
OMOM report (1990): One Market, One Money. An Evaluation of the Potential Benefits and Costs of Forming an Economic and Monetary Union. European Economy No. 44. (October), Commission of the European Communities, Directorate-General for Economic and Financial Affairs. http://ec.europa.eu/economy_finance/publications/publication7454_ en.pdf. Downloaded: 24 September 2013 and 27 March 2016.

Pagano, M. - von Thadden, E.-L. (2004): The European Bond Markets Under EMU. Centre for Studies in Economics and Finance, CSEF Working Paper, No. 126. (October). Http:// www.csef.it/WP/wp126.pdf. Downloaded: 2 April 2016.

Palánkai, T. (2012): Az önálló árfolyam-politika feladása nem okoz igazi veszteséget! (Giving up independent exchange rate policy does not cause any real loss). Economic Review, Volume LIX, June: 722-726.

Pasimeni, P. (2016): Instability and Stagnation in a Monetary Union. Institute for New Economic Thinking, Ideas \& Papers, Blog, 11 April 2016. http://ineteconomics.org/ideaspapers/blog/instability-stagnation-in-a-monetary-union. Downloaded: 15 April 2016.

Petersen, T. - Böhmer, M. - vom Stein, H. (2013): How Germany Benefits from the Euro in Economic Terms. Policy Brief No. 01. Bertelsmann Stiftung, Future Social Market Economy. https://www.ged-project.de/wp-content/uploads/2014/12/3b_PolicyBrief_Vorteile_EuroMitgliedschaft_ENGLISCH.pdf. Downloaded: 15 March 2017.

Pisani-Ferry, J. (2012): The Known Unknowns and the Unknown Unknowns of the EMU. Bruegel Policy Contribution, No. 18. (October). https://www.econstor.eu/dspace/ bitstream/10419/72123/1/728775891.pdf. Downloaded: 25 March 2016.

Ruparel, R. - Persson, M. (2011): A House Built on Sand. The ECB and the Hidden Cost of Saving the Euro. Open Europe Report No. 06. http://openeurope.org.uk/wp-content/ uploads/2011/06/a_house_built_on_sand-the_ECB_and_the_hidden_cost_of_saving the_euro.pdf. Downloaded: 18 April 2016.

Santos Silva, J.M.C. - Tenreyro, S. (2010): Currency Unions in Prospect and Retrospect. Annual Review of Economics, Vol. 2: 51-74. https://doi.org/10.1146/annurev. economics.102308.124508.

Schmidt, C.M. - Weigert, B. (2013): Weathering the Crisis and Beyond: Perspectives for the Euro Area. Ruhr Economic Papers No. 409 (March). http://dx.doi.org/10.2139/ ssrn.2246763.

Schmitz, B. - von Hagen, J. (2011): Current Account Imbalances and Financial Integration in the Euro Area. Journal of International Money and Finance, 30(8): 1676-1695. http:// dx.doi.org/10.1016/j.jimonfin.2011.08.003. 
Skouras, T. (2013): The Euro Crisis and its Lessons from a Greek Perspective. Society and Economy, Vol. 35, No. 1 (April): 51-69. http://dx.doi.org/10.1556/SocEc.35.2013.1.3.

Szijártó, N. (2014): Az optimális valutaövezet elméletek koevolúciója (Co-evolution of the theory of optimum currency areas). Occasional papers 105. (May), Hungarian Academy of sciences (MTA) Economics and Regional Sciences Research Centre, Global Economy Institute. 